\title{
Determinants of International Competitiveness of SMEs in a Developing Economy: Evidence from Bangladesh
}

\author{
Md. Nur Alam Siddik ${ }^{1}$ \\ ${ }^{1}$ Department of Finance and Banking, Begum Rokeya University, Rangpur, Bangladesh \\ Correspondence: Dr. Md. Nur Alam Siddik, Department of Finance and Banking, Begum Rokeya University, \\ Rangpur-5400, Bangladesh. E-mail: nasiddikbru@gmail.com
}

Received: November 28, 2017

Accepted: December 12, 2017

Online Published: December 20, 2017

doi:10.5539/ijbm.v13n1p266

URL: https://doi.org/10.5539/ijbm.v13n1p266

\begin{abstract}
While small and medium-sized enterprises (SMEs) are playing a vital role in the development process of countries, there is lack of studies examining the issue of international competitiveness of SMEs. Therefore this study fills this gap. The objective of this paper is to identify and explain determinants of international competitiveness of SMEs from developing economies, Bangladesh. Primary data from a sample of 130 SMEs in agriculture and agro-processed goods-oriented industries in Bangladesh were analysed using logistic model to empirically identify the determinants of SMEs international competitiveness. Results suggest that the access to finance, entrepreneurial factors, government policies, technological factors and number of countries to export are significant determinants of exports of SMEs. Findings of this study are of greater importance to the SMEs and policymakers of developing economies like Bangladesh, because on the one side, using findings of this study, managers of SMEs can run their organizations in a manner to compete with their counterparts throughout the world. On the hand concerned policy makers can use these findings to undertake conducive polices to foster export business of SMEs which ultimately will lead to the acceleration of the economic growth of the country.
\end{abstract}

Keywords: Small and medium-sized enterprises, exports, Bangladesh

\section{Introduction}

A vibrant Small and Medium Enterprises (SMEs) sector is central to the economic development of developing countries and thus studying international competiveness of SME sector of developing nations is of greater significance. SMEs encourage private ownership and innovative skills and can adapt quickly to varying market situations, create employment opportunities, diversify economic activities, and contribute significantly to exports of a country. As such SMEs have attracted a growing interest from academicians, policy makers, businessmen and researchers across the world. In Bangladesh, this sector is considered as the driving force for industrialization as because with cheap labour SME sector is more capable to generate employment and thus increase national income. Accordingly, policies and strategies to foster SMEs and to increase their international competitiveness are a priority for Bangladesh.

Exports of SME sector, especially from developing countries, plays a vital role in country's development process as it exemplify economic opportunities (Peña-Vinces et al., 2012). Recognizing the importance, there exists a chunk of studies examined the factors of international competitiveness of enterprises of developed countries (Buckley et al., 1990; Cho et al., 2007; Dunning \& Lundan, 1998; Elenurm, 2007; Fahy, 2002; Jones \& Crack, 2001). There have been, however, very few studies carried out in developing countries. As the developing countries economic structure, behaviour, political and educational systems and level of industrialization differs from the same of developed countries, findings based on studies of developed countries cannot be always applicable to developing countries. (Casanova, 2004; Cuervo-Cazurra, 2008; Peña-Vinces et al., 2012).

In the context of Bangladesh, a very few studies exists that are related to this discourse, though none of them are focused on the international competiveness of SME sector. Mintoo (2006), for example, by using the data of 1999-2004, described that contribution of SME sector to the GDP of Bangladesh had increased significantly. Ahmed and Chowdhury (2009) observed that performance of SMEs, measured by employee turnover rate, quality assurance, allocation of funds, of Bangladesh is below international standard. Authors also found the development rate of SMEs is very low. 
Bangladesh is an agro-based country. Now a days, after meeting the domestic demand, a number of agro-products such as vegetables, fruits, fish, are being exported and thus contributing more to the development process of the country. As such, agro-based SME sector is more prospective and hence efforts such as more researches, policies and strategies should be taken to boost up the exportable agricultural products. From the above discussions, it is evident that to date, there is no study investigating the determinants of international competiveness of SMEs operating in Bangladesh. In this study, we attempted to explore the determinants of international competiveness of SMEs of agriculture and agro-processed goods, since Bangladesh is an agro-based country and the agriculture sector is considered as the most diversified one.

\section{Literature Review}

\subsection{Definition of sme in Bangladesh}

The definition of small and medium-sized enterprises (SMEs) varies from country to country. In Bangladesh, a number of criteria, with changing nature, have been used to distinguish between 'micro', 'small' and 'medium' enterprises. Presently it is being defined as follows:

Table 1. Definition of SME in Bangladesh (Note 1)

\begin{tabular}{llllll}
\hline \multirow{2}{*}{ Type } & \multirow{2}{*}{ Sector } & \multicolumn{2}{c}{ Fixed asset, other than land and building } & \multirow{2}{*}{ Employed manpower } \\
\cline { 3 - 4 } & & BDT (In Million) & \multicolumn{1}{c}{ U.S Dollar* } & \\
\hline \multirow{2}{*}{ Micro } & Manufacturing & $1.0-7.5$ & $\$ 12,294-\$ \$ 92,213$ & $16-30$ \\
& Service & Less than 1.0 & Less than $\$ 12,294$ & 15 \\
& Business & Less than 1.0 & Less than $\$ 12,294$ & 15 \\
& Manufacturing & $7.5-150$ & $\$ 92,213-\$ 18,44,258$ & $31-120$ \\
\multirow{2}{*}{ Small } & Service & $1.0-20$ & $\$ 12,294-\$ 245,872$ & $16-50$ \\
& Business & $1.0-20$ & $\$ 12,294-\$ 245,872$ & $16-50$ \\
\multirow{2}{*}{ Medium } & Manufacturing & $150-500$ & $\$ 18,44,258-\$ 61,47,527$ & $121-300$ \\
& Service & $20-300$ & $\$ 245,872-\$ 3,687,450$ & $51-120$ \\
\hline
\end{tabular}

$* 1 \mathrm{USD}=81.3430 \mathrm{BDT}($ Note 2$)$.

According to Zaman and Islam (2011), in Bangladesh, there are 31 million people employed in the micro, small and medium enterprises and more than three quarters of the household income are provided by the SMEs. Also, SMEs in Bangladesh represents 99 percent of industrial units contributing over 85 per cent of industrial employment, including micro enterprises comprise over 99 per cent of all industrial units, contributing over 85 per cent of total employment of industrial sector. So, it is envisaged that SME sector has a greater contribution to the economy of Bangladesh and thus studying international competitiveness of SME sector is of greater significance.

\subsection{Theoretical Perspective on SMEs Competitiveness}

Since SMEs are small in size, this type organizations are more exposed to changes in the business atmosphere around the world. As such managers of SMEs have to undergo rigorous analysis of identification of opportunities and threats that they might face in such changing business world. Until 2000, researchers around the globe used Porter (1998) model to analyze the international competiveness of firms and economies. Considering the fact that Porter (1998) model doesn't recognize the international context, (Chen \& Lin, 2006; Hitt et al., 2006; Moon $\&$ Lee, 2004) suggested that while assessing international competitiveness, not only a local view but also the capability of local businesses for venture abroad should be taken into account. Similarly, Cerrato and Depperu (2011) strongly argued that firms' competitiveness refers to the degree of capability of firms to efficiently compete in domestic and international markets. Referring to the international of competitiveness of firms, (Cerrato \& Depperu 2011; Zeng et al., 2008) used market share, export performance to measure the international performance of firms. On the other hand, According to (Barney, 1996; Fahy, 2002)Resource Based View (RBV) considers that all firms' resources are not same and some particular resources of firms have competitive advantage and thus RBV plays a crucial role in determining firms' international competitiveness. In essence, Porter (1998) model considers the external, industry-level, features; Whereas, in addition to recognizing the fact that for developing economies, institutional factors are much important, RBV depicts the significance of internal resources of firms (Welter \& Smallbone, 2011).

Based on the complexity of the competing drivers, researchers adopted a combination of both theories discussed 
above by considering external and internal factors. For example, Man et al., (2002), applied four constructs of SME competitiveness external factors, internal factors, entrepreneur profile, and firm performance. In addition to use of the RBV based determinants where external factors were separated as industry conditions and government regulations and internal factors were operational, Sirikrai and Tang (2006) considered financial and non-financial firm's performance indicators to assess the international competitiveness of firms. In the context of Chinese SMEs competitiveness, Yan (2010) proposed a model which incorporates strategic alliances, innovation and differentiation strategies of firms and found that variables considered are significant. Using data of less developed countries, Awuah and Amal (2011) observed of less developed countries, Awuah and Amal (2011) observed that innovation, learning, and internationalization as determinants for SME competitiveness. Based on the literatures discussed above, we propose a model of determinants of international competiveness of SMEs located in Bangladesh where we consider firm's internal factors, entrepreneurial factors and institutional factors as determinants.

\section{Research methodology}

\subsection{Selection of Sample}

Our main interest is of SMEs which produce and exports agriculture and agro-processed goods. Agriculture goods include fresh vegetables and fruits, potato, tea, tobacco, meat etc. Processed food are those which are prepared using agricultural products. Spices, rice, puffed rice, juice, canned food, snakes, mustard oil, rice bran oil and so on are the agro-based processed food. Due to the classification of the agriculture and agro-processed goods into groups we adopted stratified sampling technique. From the export promotion bureau of Bangladesh, we have collected a comprehensive list, with address, of 376 manufacturers and exporters of agriculture and agro-processed goods and then send them a structured questionnaire during the month of April, 2017. We also contacted them over the phone to make sure that they have received the questionnaire. Out of 376 manufacturers and exporters, 198 responded. To serve our purpose, we adopted following criteria to be included in our sample:

i) The firm must be small or medium-sized in order to adhere to the definition of SMEs as put forward by Bangladesh government.

ii) The exporting firm must have a minimum of five years of experience, excluding domestic market experience. Adopting the selection criteria, we get 130 SMEs eligible for analysis purpose.

\subsection{Formulation of Hypotheses}

Based on the literatures discussed above, we have formulated hypotheses of determinants of SMEs international competitiveness. According to Awuah and Amal (2011), firms with more innovative activities are more able to internationalize their business, exploit opportunities home and abroad and face globalisation challenges. Arguing that innovation activities contributes positively to SMEs international competitiveness, we formulate the following hypothesis:

H1: There is a relationship between innovative adoption and SMEs international competitiveness.

Firms operate in different economies with varying business and economic environments and as such subject to face diverse challenges. Martins (2010) argued that the more the government support would be provided to SME exporters resolve problems at home and abroad, the more the SMEs international competitiveness would be. Based on the same premise, we formulate the following hypothesis:

H2: Government support for SMEs exporters have positive influence on international competitiveness of SMEs

In order to be competitive in international markets, SMEs are required to have characteristics of risk taking, pro-activeness, innovativeness and competitiveness. In addition they also have to face the changing business world and consumers' need. (Arshad et al. 2014; Zeebaree \& Siron 2017) observed a positive impact of entrepreneurial orientation on firm performance. We believe that entrepreneurial characteristics are positively related to the SMEs international competitiveness and thus postulate the following hypothesis:

H3: There is positive relationship between entrepreneurial orientation and SME international competitiveness.

It is commonly argued that experienced firm, who are in business for more years, will have the opportunity to perform better than that of the firms that just started business of the same industry. Haenfler and Johnson (2002) found that older firms have more competitive advantage in the export market than that of younger firms. Arguing the same, we formulate the following hypothesis:

H4: Number of years in business positively influences SME international competitiveness.

Another important determinant of SMEs international competiveness is the size of SMEs. Akben-Selcuk (2016) 
found a positive influence of size on Turkish firms' competitiveness and thus concluded that larger firms are more likely to be effective exporters than firms small in size. Thus, we propose the following hypothesis:

H5. SME's size has positive influences on its international competitiveness

Table 2. Summary of the research hypotheses

\begin{tabular}{|c|c|c|}
\hline & Hypotheses & Prior Studies \\
\hline $\mathrm{H} 1$ & $\begin{array}{l}\text { There is a relationship between innovative adoption and SMEs } \\
\text { international competitiveness }\end{array}$ & Awuah and Amal (2011) \\
\hline $\mathrm{H} 2$ & $\begin{array}{l}\text { Government support for SMEs exporters have positive influence } \\
\text { on international competitiveness of SMEs }\end{array}$ & $\begin{array}{l}\text { Martins (2010), Cho et al., (2008), } \\
\text { Abor et al., (2014) }\end{array}$ \\
\hline $\mathrm{H} 3$ & $\begin{array}{l}\text { There is positive relationship between entrepreneurial orientation } \\
\text { and SME international competitiveness }\end{array}$ & $\begin{array}{l}\text { Brouthers et al., (2009), Mudalige } \\
\text { et al., (2016) }\end{array}$ \\
\hline $\mathrm{H} 4$ & $\begin{array}{l}\text { Number of years in business positively influences SME } \\
\text { international competitiveness }\end{array}$ & Haenfler and Johnson (2002) \\
\hline H5 & $\begin{array}{l}\text { SME's size has positive influences on its international } \\
\text { competitiveness }\end{array}$ & Akben-Selcuk (2016) \\
\hline
\end{tabular}

\subsection{Variables Considered in the Study}

Since the main of this study is to identify the determinants of SMEs international competitiveness, the dependent variable is SMEs international competitiveness which we measured by SMEs involvement in export business. Following the work of Appiah et al., (2015) and Mittelstaedt et al., (2003) we measure the involvement of SMEs by their activeness in export business. If SME is active in export business, it takes value 1, otherwise 0 . Based on the prior studies, following table summarizes independent variables considered in our model:

Table 3. Summary of the independent variables considered and their legend

\begin{tabular}{lll}
\hline & Variable name & Legend \\
\cline { 2 - 3 } & Innovation activities & IA \\
& Access to finance & AF \\
& Trade promotional activities & TP \\
& Entrepreneurial factors & EF \\
Independent Variables & Government policies & GP \\
& Technological factors & TF \\
& Number of countries the SME export & NC \\
\hline
\end{tabular}

\subsection{Regression model}

In order to determine the international competiveness of SMEs, following the work of Appiah et al. (2015), we adopted and applied logistic regression model as follows:

$$
\operatorname{logit}(p)=\beta_{0}+\beta_{1} X_{1}+\beta_{2} X_{2}+\beta_{3} X_{3}+\ldots \ldots . .+\beta_{k} X_{k}
$$

In the above model, $\mathrm{p}$ is the probability of the characteristic of interest

$$
\text { Odds }=\frac{p}{1-p}=\frac{\text { Probaility of presence of characteristic }}{1-\text { Probaility of presence of characteristic }}
$$

and

$$
\operatorname{logit}(p)=\ln \left(\frac{p}{1-p}\right)
$$

\section{Results and discussion}

We present this section in two parts. First part exhibits the descriptive statistics of data set whereas the second part reflects the inferential statistics.

\subsection{Descriptive Statistics}

We aimed to get the key information. According to Table 4, the highest $46.15 \%$ respondents were the managing 
directors followed by 33\% export managers who usually have key information and deep knowledge and understanding of their SME. The third highest respondents were the assistant managing director who presumed to have better understanding of the nature and strategies of the SME. Thus, it could be argued that, based on the survey we received the valuable information about the SMEs.

Table 4. Respondent's position

\begin{tabular}{lll}
\hline Respondent's position & Frequency & Percentage \\
\hline Managing Director & 60 & 46.15 \\
Assistant Managing Director & 26 & 20.00 \\
Production Manager & 9 & 6.92 \\
Export Manager & 33 & 25.38 \\
Administration Officer & 2 & 1.54 \\
Total & 130 & 100.00 \\
\hline
\end{tabular}

According to Blunck and Martin (2011), with more number of years in business, firms slowly gain experience about changing nature of business and then undertake methodological strategies to face the situations. Since this study investigates the international competiveness of SMEs, data set reflects the same as we see in Table 5 that highest 43.08\% SMEs engaged in export business for 11-15 years, followed by $21.54 \%$ engaged for 5-10 years. As per Table 5, more than $97 \%$ sample SMEs have engaged in export business for more number of years, so data fits our purpose of investigation.

Table 5. Years in export business

\begin{tabular}{lll}
\hline Respondent's position & Frequency & Percentage \\
\hline Managing Director & 60 & 46.15 \\
Assistant Managing Director & 26 & 20.00 \\
Production Manager & 9 & 6.92 \\
Export Manager & 33 & 25.38 \\
Administration Officer & 2 & 1.54 \\
Total & 130 & 100.00 \\
\hline
\end{tabular}

One of the main challenges of SMEs in international market is of limited resources to face the global competition. Though Cavusgil and Knight (2004) opined that firms with less resources still can experience better performance when combined more entrepreneurial capability, our study is based on developing economy with much more constraints to entrepreneurship. Thus, we argue that, size can affect the firm performance. Our data set also describes the same as can be seen from Table 6 that a total of about 93\% SMEs have employees more than five where the highest $28.46 \%$ is the case for 16 to 20 employees followed by $25.38 \%$ is the case for more than 40 employees.

Table 6. Size of the firm

\begin{tabular}{lll}
\hline Number of employees & Frequency & Percentage \\
\hline less than 5 & 4 & 3.08 \\
5 to 10 & 7 & 5.38 \\
11 to 15 & 17 & 3.08 \\
16 to 20 & 37 & 28.46 \\
21 to 30 & 27 & 20.77 \\
31 to 40 & 5 & 3.85 \\
More than 40 & 33 & 25.38 \\
Total & 130 & 100.00 \\
\hline
\end{tabular}

To get the picture of what innovation activities are undertaken by the SMEs, respondents were asked on following issues on a five-point likert scale ranging from strongly disagree(1) to strongly agree (5). As shown in Table 7, the highest innovation activities of SMEs, with a mean value of 4.87 , was that they applied research 
findings to become internationally more competitive followed by the fact that SMEs have available research and development units.

Table 7. Innovative activities

\begin{tabular}{lllllll}
\hline Innovative Activities & N & Range & Min & Max & Mean & SD \\
\hline Availability of R \& D unit & 130 & 4 & 1 & 5 & 2.31 & 1.01 \\
Sufficient expert for R \& D & 130 & 3 & 1 & 4 & 1.97 & 1.04 \\
Use of research findings & 130 & 4 & 1 & 5 & 4.87 & 0.091 \\
Professional training of R \& D unit & 130 & 3 & 1 & 4 & 1.62 & 0.92 \\
\hline
\end{tabular}

Table 8 reveals the sources of finance used by the SMEs where we used the same five-point likert scale as indicated in case of Table 7. It can be seen from the table that SMEs mostly use their own fund to meet the financing need of their organizations which is indicated by the highest mean value of 4.44.The second most source of fund they applied is bank loan to meet their working capital requirements.

Table 8. Sources of finance

\begin{tabular}{lllllll}
\hline Financial Instruments & N & Range & Min & Max & Mean & SD \\
\hline Bank loan for working Capital & 130 & 3 & 1 & 4 & 2.26 & 1.05 \\
Overdraft & 130 & 3 & 1 & 4 & 1.37 & 0.53 \\
Financial leasing (for procurement of equipment, automobiles) & 130 & 2 & 1 & 3 & 1.48 & 0.76 \\
Venture capital & 130 & 3 & 1 & 4 & 1.11 & 0.38 \\
Loan from family and friends & 130 & 3 & 1 & 4 & 2.13 & 1.04 \\
Owner(s) own finance & 130 & 2 & 2 & 4 & 4.44 & 0.43 \\
Government funding & 130 & 4 & 1 & 5 & 1.72 & 1.24 \\
\hline
\end{tabular}

Following George and Marino (2011), we adopted four components of Entrepreneurial Orientation of SMEs, namely Innovativeness, Proactiveness, Risk Taking and Competitiveness. On a basis of five-point likert scale, we observed, as shown in Table 9, that risk taking, with a mean value of 4.22 is the highest priority component of entrepreneurial orientation. This implies that exporters have to undertake risk while doing export business.

Table 9. Entrepreneurial orientation

\begin{tabular}{lllllll}
\hline Entrepreneurial Orientation & N & Range & Min & Max & Mean & SD \\
\hline Innovative & 130 & 3 & 1 & 4 & 3.62 & 0.73 \\
Proactiveness & 130 & 4 & 1 & 5 & 3.29 & 1.01 \\
Risk Taking & 130 & 2 & 2 & 4 & 4.22 & 0.59 \\
Competitiveness & 130 & 4 & 1 & 5 & 4.01 & 0.54 \\
\hline
\end{tabular}

According to Newbert (2008), in order to achieve competitive advantage, a firm has to exploit a combination of valuable research-capability with a greater focus on use of modern technologies including internet. Findings provided in Table 10 indicate that SME exporters mostly use internet for the purpose of sending and receiving emails along with documents followed by use of SME's websites and online sales.

Table 10. Use of internet by SME exporter

\begin{tabular}{lllllll}
\hline Impact purpose of internet Usage & N & Range & Min & Max & Mean & SD \\
\hline Send and receive e- mails and documents & 130 & 3 & 1 & 4 & 4.32 & 0.53 \\
Tracking shipments & 130 & 3 & 2 & 5 & 3.27 & 1.21 \\
Company's websites and online sales & 130 & 4 & 1 & 5 & 3.84 & 0.78 \\
\hline
\end{tabular}

Considering government policies as key determinant of SME exports, respondents were asked to reply on five-point likert scale. Government policy with the highest mean value of 3.7 is export trade information followed by support from export association, with a mean value of 3.67. However, according the findings provided in Table 11, SMEs are not getting support from Bangladeshi high commissions abroad, with the least mean value of 2.11. Also, SMEs are not getting from state government of Bangladesh. Thus, we could say that 
lack of government supports is acting as impediments to achieve international competiveness of SMEs located in Bangladesh.

Table 11. Government support

\begin{tabular}{llllll}
\hline Government policies & N & Min & Max & Mean & SD \\
\hline Support from Export Association & 130 & 2 & 5 & 3.67 & 0.81 \\
Export Trade Information & 130 & 1 & 4 & 3.7 & 0.76 \\
Technical/Production support & 130 & 1 & 4 & 3.33 & 1.02 \\
Support from the state Government & 130 & 1 & 5 & 2.22 & 1.04 \\
Participation in exhibition & 130 & 2 & 5 & 3.19 & 1.13 \\
Sourcing export finance & 130 & 2 & 4 & 2.11 & 1.03 \\
Support from Bangladesh High Commissions Abroad & 130 & 1 & 4 & 1.87 & 0.67 \\
\hline
\end{tabular}

\subsection{Inferential Analysis}

In this subsection, we present the inferential statistics and their discussion.

\subsubsection{Reliability and Validity of Measurement Tools}

Before moving for final data analysis, we assessed the reliability of the research instrument and validity of construct. We applied Cronbach's alpha test and found the least alpha value among all dimensions is 0.711 . Thus, following the suggestion of Hair et al., (1995) about minimum alpha value of 0.65 , our constructs are reliable. In order to check the suitability of application of factor analysis, sampling adequacy was computed by means of the Kaiser-Meyer-Olkin (KMO) approach. We found measure of sampling adequacy $(\mathrm{MSA})=0.725$, $\mathrm{p}<001$ which states that data of collected sample on 130 SMEs is suitable to conduct an exploratory factor analysis (EFA) and as such we conducted the EFA. Using principal component analysis and varimax rotation method, a total of 5 factors with eigenvalues greater than one were extracted and these factors explained $69.79 \%$ of the total variance. All factor loadings, as shown in Table 12, were found as higher than 0.6 which reflects that the minimum factor loadings are adequately met.

Table 12. Cronbach's alpha and factor loadings

\begin{tabular}{|c|c|c|c|c|c|c|c|c|}
\hline \multirow{2}{*}{ Factor } & \multirow{2}{*}{ Item } & \multicolumn{5}{|c|}{ Component } & \multirow{2}{*}{ Cronbach's } & \multirow{2}{*}{ Alpha } \\
\hline & & 1 & 2 & 3 & 4 & 5 & & \\
\hline \multirow{6}{*}{ Innovative activities } & IA1 & .101 & .032 & .789 & -.031 & .083 & \multirow{7}{*}{.711} & \\
\hline & IA2 & .021 & .043 & .666 & -.210 & -.001 & & \\
\hline & IA3 & -.023 & .111 & .651 & .033 & .021 & & \\
\hline & IA 4 & .107 & .040 & .617 & -.138 & -.037 & & \\
\hline & $\mathrm{AF} 1$ & -.101 & -.023 & -.111 & .777 & -.017 & & \\
\hline & AF2 & .010 & -.034 & -.048 & .734 & .045 & & \\
\hline & AF3 & -.101 & -.028 & -.045 & .718 & .120 & & \\
\hline \multirow{5}{*}{ Access to finance } & AF4 & .034 & .023 & .123 & .702 & -.097 & \multirow{6}{*}{.732} & \\
\hline & AF5 & .101 & .112 & .113 & .694 & -.027 & & \\
\hline & AF6 & .029 & .056 & .151 & .667 & -.025 & & \\
\hline & AF7 & .111 & .025 & .018 &. & -.018 & & \\
\hline & EO1 & .031 & .676 & .218 & .011 & .027 & & \\
\hline \multirow{3}{*}{ Entrepreneurial Orientation } & $\mathrm{EO} 2$ & .026 & .652 & .118 & -.072 & -.117 & & \\
\hline & EO3 & -.003 & .645 & -.023 & -.019 & .010 & \multirow{2}{*}{.785} & \\
\hline & EO4 & .024 & .631 & -.001 & -.028 & .028 & & \\
\hline \multirow{6}{*}{ Technology } & $\mathrm{TC} 1$ & .748 & .0137 & .185 & -.037 & -.001 & \multirow{6}{*}{.752} & \\
\hline & $\mathrm{TC} 2$ & .701 & -.013 & .111 & -.026 & -.037 & & \\
\hline & TC3 & .668 & -.021 & .032 & -.112 & .019 & & \\
\hline & GO1 & .011 & -.028 & -.016 & .115 & .789 & & \\
\hline & $\mathrm{GO} 2$ & -.028 & .019 & .013 & .014 & .777 & & \\
\hline & GO3 & .031 & -.021 & .024 & .008 & .754 & & \\
\hline \multirow{3}{*}{ Government Policies } & GO4 & .025 & .019 & .026 & -.003 & .731 & \multirow{3}{*}{.814} & \\
\hline & GO5 & -.024 & .018 & .119 & -.055 & .719 & & \\
\hline & GO6 & .033 & .034 & .071 & -.032 & .704 & & \\
\hline
\end{tabular}




\subsubsection{Discriminant analysis}

$\begin{array}{llllll}\mathrm{GO} 7 & .039 & .029 & -.021 & -.059 & \underline{\mathbf{6 9 9}}\end{array}$

In order to determine the construct's validity, following Fornell and Larcker (1981), we examined square root of the average variance extracted (AVE), and correlations between variables. According to findings provided in Table 13, the square root of each construct's AVE is higher than its correlation with another construct, presented across diagonal so discriminant validity has been established which indicate that approach adopted in this study to examine international competitiveness of Bangladeshi SMEs is appropriate.

Table 13. Discriminant analysis results

\begin{tabular}{llllllll}
\hline & IA & AF & TP & EF & GP & TF & NC \\
\hline IA & .95 & & & & & & \\
AF & 0.14 & .91 & & & & & \\
TP & -0.04 & 0.13 & .89 & & & & \\
$\mathbf{E F}$ & -0.12 & 0.41 & -0.19 & .87 & & & \\
$\mathbf{G P}$ & -0.20 & -0.23 & -0.13 & -0.36 & .85 & & \\
TF & -0.27 & -0.13 & -0.30 & 0.16 & -0.07 & .84 & \\
$\mathbf{N C}$ & -0.21 & -0.17 & 0.16 & -0.08 & 0.18 & -0.60 & .82 \\
\hline
\end{tabular}

\subsubsection{Regression Results and Discussion}

Table 14 exhibits the regression results. All variables except innovation activities (IA) and Trade promotion activities (TP), have significant positive relationship with SMEs international competiveness. We found that access to finance (AF) had a significant positive relationship with the SMEs involvement in export business which is similar the findings of Abor et al., (2014) who observed that more and easier access to finance leads to improved export performance of SMEs. This finding implies that policymakers should undertake such strategies to ensure easy and needful access to credit for SMEs. Similar the findings of Brouther et al., (2009) and Mudalige et al., (2016) we found Entrepreneurial factors had significant positive relationship with SMEs exports. This finding is imperative especially for the developing economies like Bangladesh as it requires risk taking attitude. We also observed that government policies and support factor plays a significant positive role in improving SMEs international competiveness which is consistent with the finding of Zindiye et al., (2012). Governments' supportive policies are vital to SMEs because while exporting products and services abroad, it requires ease of licensing procedure, reduced export duty and technical support from a country's high commission aboard. Without supportive policy, it would be difficult for SMEs, especially from developing economies to conduct export business. Considering the fact export from SMEs can accelerate the economic growth of the country, this finding suggest governments to undertake supportive policies for the SMEs so that share of export from SMEs could increase largely. Similar to the findings of Meltzer (2015) we found technological factors and number of countries the SME export have positive relations with the SMEs international competiveness. This is era considered as technological era. To become internationally competitive, technologies plays important roles. With the help of technologies such as internet, SMEs can conduct business worldwide very swiftly and smoothly. Also, the more the number of countries SMEs can penetrate and as such expand, the higher exports it will experience. Similar to the findings of Appiah et al., (2015), in our present study we found innovation activities and trade promotion active had negative but not significant relationships with the exports of SMEs.

Table 14. Regression results

\begin{tabular}{llllll}
\hline Variable & Coefficient & Standard Error(S.E) & Wald X2 & df & P-value \\
\hline IA & -0.215 & 0.087 & 2.911 & 1 & 0.115 \\
AF & 0.187 & 0.071 & 3.815 & 1 & $0.043^{* *}$ \\
TP & -0.022 & 0.073 & 0.081 & 1 & 0.613 \\
EF & 0.234 & 0.136 & 1.712 & 1 & $0.008^{* * *}$ \\
GP & 0.264 & 0.065 & 9.313 & 1 & $0.001^{* * *}$ \\
TF & 0.031 & 0.044 & 0.301 & 1 & $0.031^{* *}$ \\
NC & 0.931 & 0.263 & 8.312 & 1 & $0.001^{* * *}$ \\
Constant & 4.911 & 3.214 & 2.117 & 1 & $0.002^{* * *}$ \\
\hline
\end{tabular}


Note: $* *$ signifies variable significant at $5 \%, * * *$ signifies variable significant at $1 \%$

\section{Conclusions}

SMEs plays a catalytic role in the growth process of developing economies viz., Bangladesh. Considering the imperatives, with an aim to improve exports of SMEs, this study tried to explore the determinants of international competiveness of SMEs operating in Bangladesh. Using a survey data of 130 SMEs located in Bangladesh, this study finds that access to finance, entrepreneurial factors, government policies, technological factors and number of countries to export are important determinants of exports of SMEs. Findings of this study are of greater importance to the SMEs and policymakers of developing economies like Bangladesh, because on the one side, using findings of this study, managers of SMEs can run their organizations in a manner to compete with their counterparts throughout the world. On the other hand concerned policy makers can use these findings to undertake conducive polices to foster export business of SMEs which ultimately will lead to the acceleration of the economic growth of the country.

One of the main limitations of this study is that it is conducted only on SMEs of agriculture and agro-processed goods and thus might not be applicable for other type SMEs. We believe, consideration of other type SMEs would make findings more rigorous and generalizable. Anther limitation is that this is a cross-sectional study based on one period data. We believe a longitudinal study would provide more insights and deeper understanding of the investigated issue and so in future such longitudinal studies would be conducted which will then could be compared with our findings.

\section{References}

Abor, J. Y., Agbloyor, E. K., \& Kuipo, R. (2014). Bank finance and export activities of small and medium enterprises. Review of Development Finance, 4(2), 97-103. https://doi.org/10.1016/j.rdf.2014.05.004

Ahmed, K., \& Chowdhury, T. A. (2009). Performance evaluation of SMEs of Bangladesh. International journal of Business and Management, 4(7), 126-133. http://dx.doi.org/10.5539/ijbm.v4n7p126

Akben-Selcuk, E. (2016). Factors affecting firm competitiveness: Evidence from an emerging market. International Journal of Financial Studies, 4(2), 1-10. https://doi.org/10.3390/ijfs4020009

Appiah, K., Selassie, H., \& Burnley, R. (2015). Determinants of SME international competitiveness: a case of Ghanaian horticultural exporters. The Business \& Management Review, 6(3), 191.

Arshad, A. S., Rasli, A., Arshad, A. A., \& Zain, Z. M. (2014). The impact of entrepreneurial orientation on business performance: A study of technology-based SMEs in Malaysia. Procedia-Social and Behavioral Sciences, 130, 46-53. https://doi.org/10.1016/j.sbspro.2014.04.006

Awuah, G.B., \& Amal, M. (2011). Impact of globalisation: the ability of less developed countries (LDCs) firms to cope with opportunities and challenges. European Business Review, 23(1), 120-32. https://doi.org/10.1108/09555341111098026

Barney, J. B. (1996). The resource-based theory of the firm. Organization science, 7(5), 469-469. https://doi.org/10.1287/orsc.7.5.469

Blunck, E., \& Martin, M. (2011). International Consulting Cooperative for SMEs going abroad-Drivers, challenges and a proposal based on the cooperative model (pp. 127-176). Stuttgart: University of Hohenheim.

Brouthers, L. E., Nakos, G., Hadjimarcou, J., \& Brouthers, K. D. (2009). Key factors for successful export performance for small firms. Journal of International Marketing, 17(3), 21-38. https://doi.org/10.1509/jimk.17.3.21

Buckley, P. J., Pass, G. L., \& Prescott, K. (1990). Measures of international competitiveness: empirical findings from British manufacturing companies. Journal of Marketing Management, 6(1), 1-13. https://doi.org/10.1080/0267257X.1990.9964112

Casanova, L. (2004). East Asian, European, and North American multinational firm strategies in Latin America. Business and Politics, 6(1), 1-38. https://doi.org/10.2202/1469-3569.1074

Cavusgil, S. T., \& Knight, G. (2015). The born global firm: An entrepreneurial and capabilities perspective on early and rapid internationalization. Journal of International Business Studies, 46(1), 3-16. https://doi.org/10.1057/palgrave.jibs.8400056

Cerrato, D., \& Depperu, D. (2011). Unbundling the construct of firm-level international competitiveness. Multinational Business Review, 19(4), 311-331. https://doi.org/10.1108/15253831111190162 
Cho, D. S., Moon, H. C., \& Kim, M. Y. (2008). Characterizing international competitiveness in international business research: A MASI approach to national competitiveness. Research in International Business and Finance, 22(2), 175-192. https://doi.org/10.1016/j.ribaf.2007.04.002

Chen, Y. M., \& Lin, F. J. (2006). Regional development and sources of superior performance across textile and IT sectors in Taiwan. Entrepreneurship and Regional Development, 18(3), 227-248. https://doi.org/10.1080/08985620600676560

Cuervo-Cazurra, A. (2008). The multinationalization of developing country MNEs: The case of multilatinas. Journal of international Management, 14(2), 138-154. https://doi.org/10.1016/j.intman.2007.09.001

Dunning, J. H., \& Lundan, S. M. (1998). The geographical sources of competitiveness of multinational enterprises: an econometric analysis. International Business Review, 7(2), 115-133. https://doi.org/10.1016/S0969-5931(98)00001-8

Elenurm, T. (2007). International competitiveness and organizational change drivers anticipated by Estonian managers in the context of European integration. Baltic Journal of Management, 2(3), 305-318. https://doi.org/10.1108/17465260710817500

Fahy, J. (2002). A resource-based analysis of sustainable competitive advantage in a global environment. International Business Review, 11(1), 57-77. https://doi.org/10.1016/S0969-5931(01)00047-6

Fornell, C., \& Larcker, D. F. (1981). Evaluating structural equation models with unobservable variables and measurement error. Journal of marketing research, 18(1), 39-50. https://doi.org/10.2307/3151312

George, B. A., \& Marino, L. (2011). The epistemology of entrepreneurial orientation: Conceptual formation, modeling, and operationalization. Entrepreneurship Theory and Practice, 35(5), 989-1024. https://doi.org/10.1111/j.1540-6520.2011.00455.x

Haenfler, R., \& Johnson, B. (2002). Learning-by-doing as a propagation mechanism. The American Economic Review, 92(5), 1498-1520. https://doi.org/10.1257/000282802762024601

Hair Jr, J. F., Anderson, R. E., Tatham, R. L., \& William, C. (1995). Multivariate data analysis with readings. New Jersy: Prentice Hall.

Jones, M. V., \& Crick, D. (2001). High technology firms' perceptions of their international competitiveness. Strategic Change, 10(3), 129-138. https://doi.org/10.1002/jsc.522

Man, T. W., Lau, T., \& Chan, K. F. (2002). The competitiveness of small and medium enterprises: A conceptualization with focus on entrepreneurial competencies. Journal of business venturing, 17(2), 123-142. https://doi.org/10.1016/S0883-9026(00)00058-6

Martins, A. (2010). Destination problems confronting SME export ers from developing countries. In The Proceedings of LMBS 3rd Annual Research Conference, held 30th June.

Meltzer, J. (2015). Using the Internet to promote services exports by small-and medium-sized enterprises. Brookings Global Working Paper Series. Retrieved May 20, 2017, from https://www.brookings.edu/wp-content/uploads/2016/06/Internet-WP_WEB-Final.pdf

Mintoo, A. A. (2006). SMEs in Bangladesh. CACCI Journal, 1(1), 1-19.

Mittelstaedt, J. D., Harben, G. N., \& Ward, W. A. (2003). How small is too small? Firm size as a barrier to exporting from the United States. Journal of Small Business Management, 41(1), 68-84. https://doi.org/10.1111/1540-627X.00067

Moon, H. C., \& Lee, D. (2004). The competitiveness of multinational firms: A case study of Samsung Electronics and Sony. Journal of International and Area Studies, 11(1), 1-21.

Mudalige, D., Ismail, N. A., \& Malek, M. A. (2016). Exploratory study on relationship between entrepreneur characteristics and dynamic capabilities in export SMES. Paradigm, 20(2), 113-130. https://doi.org/10.1177/0971890716672934

Newbert, S. L. (2008). Value, rareness, competitive advantage, and performance: a conceptual - level empirical investigation of the resource based view of the firm. Strategic management journal, 29(7), 745-768. https://doi.org/10.1002/smj.686

Peña-Vinces, J. C., Cepeda-Carrión, G., \& Chin, W. W. (2012). Effect of ITC on the international competitiveness of firms. Management Decision, 50(6), 1045-1061. https://doi.org/10.1108/00251741211238328 
Sirikrai, S. B., \& Tang, J. C. (2006). Industrial competitiveness analysis: Using the analytic hierarchy process. The Journal of High Technology Management Research, 17(1), 71-83. https://doi.org/10.1016/j.hitech.2006.05.005

Welter, F., \& Smallbone, D. (2011). Institutional perspectives on entrepreneurial behavior in challenging environments. Journal of Small Business Management, 49(1), 107-125. https://doi.org/10.1111/j.1540-627X.2010.00317.x

Yan, S. (2010). Competitive strategy and business environment: The case of small enterprises in China. Asian Social Science, 6(11), 64-71. http://dx.doi.org/10.5539/ass.v6n11p64

Zaman, A. H., \& Islam, M. J. (2011). Small and medium enterprises development in Bangladesh: Problems and prospects. ASA University Review, 5(1), 145-160.

Zeebaree, M. R. Y., \& Siron, R. B. (2017). The Impact of Entrepreneurial Orientation on Competitive Advantage Moderated by Financing Support in SMEs. International Review of Management and Marketing, 7(1), 43-52.

Zeng, S. X., Xie, X. M., Tam, C. M., \& Wan, T. W. (2008). Competitive priorities of manufacturing firms for internationalization: an empirical research. Measuring Business Excellence, 12(3), 44-55. https://doi.org/10.1108/13683040810900395

Zindiye, S., Chiliya, N., \& Masocha, R. (2012). The impact of government and other Institutions' support on the performance of small and medium enterprises in the manufacturing sector in Harare, Zimbabwe. International Journal of Business Management \& Economic Research, 3(6), 655-667.

\section{Notes}

Note 1. https://www.bb.org.bd/mediaroom/circulars/smespd/jun292017smespd02.pdf

Note 2. http://www.xe.com/

\section{Copyrights}

Copyright for this article is retained by the author(s), with first publication rights granted to the journal.

This is an open-access article distributed under the terms and conditions of the Creative Commons Attribution license (http://creativecommons.org/licenses/by/4.0/). 